\title{
OXIDATIVE STRESS IN HUMAN THYROID GLAND UNDER IODINE DEFICIENCY NODULAR GOITER: FROM HARMLESSNESS TO HAZARD DEPENDING ON COPPER AND IODINE SUBCELLULAR DISTRIBUTION
}

\author{
H. Falfushynska', ${ }^{1,2}$, L. Gnatyshyna ${ }^{1,2}$, A. Shulgai ${ }^{1}$, V. Shidlovski ${ }^{1}$, O. Stoliar ${ }^{2}$ \\ II. YA. HORBACHEVSKY TERNOPIL STATE MEDICAL UNIVERSITY, TERNOPIL, UKRAINE \\ ${ }^{2}$ V. HNATIUK TERNOPIL NATIONAL PEDAGOGICAL UNIVERSITY, TERNOPIL, UKRAINE
}

\begin{abstract}
Background. Thyroid disorders are the second most common endocrinopathies found in humans and animals. Determination of their key molecular markers presents a special interest.

Objective. We studied iodine and copper accumulation in nodular, paranodular and contralateral (not affected tissue by node) tissues of human thyroid gland in relation to the level of metal-binding proteins, potential antioxidants, and oxidative changes in tissue for this goal. Lower level of organificated iodine and higher level and mass fraction of inorganic iodine and copper in the nodular and paranodular tissue versus contralateral part of thyroid gland was established.

Results. The level of both metal-binding and apo-form of metallothioneins was higher. Content of reduced glutathione was lower in node-affected tissue compared to the contralateral part. Signs of oxidative stress (higher activity of superoxide dismutase, catalase, glutathione-transferase and level of oxyradicals) and cytotoxicity (higher cathepsin D activity, higher level of DNA strand breaks and glycolysis activation) in affected tissue were observed. The range of indice variability in paranodular tissue was smaller than in nodule compared to the parenchyma of contralateral part.

Conclusions. Excess of copper unbound to metallothionein in goitrous-changed tissue and high level of inorganic iodine could be the reason for elevated DNA fragmentation and increased lysosomal membrane permeability and activation of antioxidant defense. The main criterions of goiter formation were represented by low level of organificated iodine and high level of DNA damage in thyroid gland.
\end{abstract}

KEY WORDS: iodine deficiency nodular colloidal goiter, iodine, copper, metallothioneins, oxidative stress, cytotoxicity

\section{Introduction}

Thyroid disorders are the second most common endocrinopathies found in humans and animals [1]. Determination of the key molecular markers is of considerable interest as they can be used to predict such pathologies. Iodine deficiency in thyroid pathology occurrence rate is rapidly increasing [2]. It has miscellaneous origins as a result of complex interaction of endogenous and exogenous factors and arises in the setting of high level of "nonspecific" goitrogens, among them copper, in the environment. Copper is an essential element for humans and animals, especially for antioxidant defense and the metabolism of the amino acid tyrosine, which is needed for the production of thyroid hormones [3]. Besides these ones, excessive amounts of copper in the body can pose a risk. The mechanisms underlying the acute toxicity effects of copper in humans are not well understood. It is reasonable to speculate that they probably represent a combination of significant oxidative stress at different body areas together with marked perturbations in several components of the endocrine system. It was shown Address for correspondence: H. Falfushynska, General Chemistry Department, I. Ya. Horbachevsky Ternopil State Medical University, m. Voli, 1, Ternopil, 46001, Ukraine Tel.: +380506782021;

E-mail: halynka.f@gmail.com that the increase of copper level in the thyroid gland of patients with colloidal goiter was combined with the prooxidant changes in tissue [4]. It should be noted that Ternopil region with combination of moderate iodine deficiency and high scale of copper water pollution [5] presents an interest to study the relationship between copper accumulation and progress of thyroid pathology.

Free radical-mediated oxidative damage has been implicated in pathogenesis of many diseases. However, the reasons of this phenomenon are disputable under endemic nodular thyroid goiter. It is believed that the prooxidant effect of copper depends on the specific accumulation by metal binding protein, such as metallothioneins [6]. Metallothioneins (MTs) are low-molecular weight proteins of 6-7 kDa, with high content of cysteine (30\%) and complete absence of aromatic amino acids and histidine, capable of binding transition metals with high affinity. MTs synthesis can be induced by a variety of metals, cytotoxic agents, stress-producing conditions, cytokines, and glucocorticoid hormones [7]. Additionally, MTs can function as efficient scavengers of reactive oxygen species to preserve homeostasis of cells. The latest study have indicated a possible role of MTs as a tumor suppressor in papillary thyroid cancer [8] and 
their part in the distribution of metals, thereby optimizing the function of thyroid gland [4].

Thus, the aim of this study was to evaluate the relation between the function of MTs and oxidative stress in node, paranodular and non-affected by node contralateral part tissue of human thyroid gland under iodine deficiency endemic nodular thyroid goiter. Molecular markers of cytotoxicity were used to assess the severity of the pathological process.

\section{Methods}

The target population in this study were the people with unilateral euthyroid iodine deficiency nodular thyroid goiter, who had lived in Ternopil Region for at least 22 years. Small samples of nodule, paranodular and contralateral (not affected by node tissue) tissues from thyroid gland were dissected in 25 patients. They were operated at the General Surgery Department of the local Ternopil Emergency Hospital. All experimental studies were conducted in accordance with the approval of the First National Congress on Bioethics (Kyiv, 2000) and the approval of the Bioethics Commission of I. Ya. Horbachevsky Ternopil State Medical University.

Tissue samples were homogenized $(1 / 10 \mathrm{w} / \mathrm{v})$ in $0.1 \mathrm{M}$ phosphate buffer, $\mathrm{pH} 7.4$, containing $100 \mathrm{mM}$ $\mathrm{KCl}$ and $1 \mathrm{mM}$ EDTA, as well as $0.1 \mathrm{mM}$ phenylmethylsulfonyl fluoride (PMSF) for proteolysis inhibition for enzymatic measurements. Homogenates were centrifuged for $10 \mathrm{~min}$ at $6,000 \mathrm{~g}$. Protein concentration in the supernatant (soluble protein) was measured by the method of Lowry et al. (1951), using bovine serum albumin as a protein standard. The absorbance values were measured on an UV/ Vis spectrophotometer "Lomo-56" (Russia), and extinction/emission values were measured on the $f$-max fluorescence microplate reader [Molecular Device (USA)].

Reduced glutathione (GSH), 5,5'-dithio-bis(2nitrobenzoic acid) (DTNB), glutathione reductase from baker's yeast (S. cerevisiae), 2-vinylpyridine, dihydrorhodamine, salmon sperm DNA, Hoescht 33342, serum albumin, phenazinemethosulfate, phenylmethylsulfonylfluoride (PMSF), $\beta$-mercaptoethanol, NADH, $\beta$-NADPH, and EDTA were purchased from Sigma-Aldrich. All chemicals were of the analytical grade or better.

MTs were determined in parts of thyroid gland tissue after ethanol/chloroform extraction by thiol measurement with DTNB according to the method of Viarengoet al. (1997) [9]. The level of MT-related thiols (MT-SH) was calculated by using following relationship: $1 \mathrm{~mol}$ MT-SH $=20 \mathrm{~mol} \mathrm{GSH}$. The level of MTs was defined as $\mu \mathrm{g}$ of MTs per gram of fresh weight (FW) tissues. To assess metal concentration in the MTs (MT-Me), they were isolated as thermostable proteins by size-exclusion chromatography on Sephadex G-50 with necessary adjustments needed to avoid their oxidation [10], as described previously [11]. A $5 \%$ homogenate (w/v) was prepared in ice-cold $10 \mathrm{mM}$ Tris-HCl buffer, $\mathrm{pH}$ 8.0, containing $10 \mathrm{mM}$ 2-mercaptoethanol for maintaining of the reduced conditions and $0.1 \mathrm{mM}$ PMSF for the inhibition of proteolysis. Fractions of the chromatographic peak with high absorbance at $254 \mathrm{~nm}$ and comparative high density ratio $\mathrm{D}_{254} / \mathrm{D}_{280}$, identified as MT-containing peak [12], were pooled (total $10 \mathrm{~mL}$ ) and applied to metal determination.

To determine copper and zinc concentration, fresh tissues $(500 \mathrm{mg})$ and pooled eluate of MTs fraction after the size-exclusion chromatography $\left(10 \mathrm{~mL}\right.$ ) were digested in $5 \mathrm{~mL} \mathrm{HNO}_{3}$ (Merck) for $3 \mathrm{~h}$ at $105^{\circ} \mathrm{C}$ for metal analysis using hermetic acidcleaned Teflon bomb. Concentration of metals was analyzed by the atomic absorption spectrometer with flame detector (C-115, "LOMO", Russian Federation). The metal detection limits were $0.1 \mu \mathrm{g} \cdot \mathrm{g}^{-1}$ FW. The analytical methods were validated by external intercalibrations. Quality control was assessed by the Quality Control Sample of trace metal and method of Standard Addition (www.dentalmercury.com/245_1.pdf). Metal concentration in the tissues and MTs was presented as $\mu \mathrm{g} \cdot \mathrm{g}^{-1} \mathrm{FW}$ and $\mathrm{nmol} \cdot \mathrm{g}^{-1} \mathrm{FW}$. Subcellular distribution of iodine in the thyroid gland was determined by previously developed method [13].

Superoxide dismutase (SOD, EC 1.15.1.1) activity was measured by the method of Beauchamp and Fridovich (1971) [14] based on the aerobic reduction of NBT at $535 \mathrm{~nm}$ by superoxide radicals and expressed as units $\mathrm{mg}^{-1}$ soluble protein; 1 unit of SOD activity is defined as the amount of protein causing $50 \%$ inhibition of the rate of NBT reduction.

Catalase (EC 1.11.1.6) activity was measured by monitoring decomposition of $10 \mathrm{mM} \mathrm{H}_{2} \mathrm{O}_{2}$ according to Aebi (1974) [15] at $240 \mathrm{~nm}\left(\varepsilon=40 \mathrm{M}^{-1} \cdot \mathrm{cm}^{-1}\right)$ in buffer containing $50 \mathrm{mM} \mathrm{KH}_{2} \mathrm{PO}_{4}(\mathrm{pH} 7.0)$ and approximately $150 \mu \mathrm{g}$ of proteins. The results were related to soluble protein.

Total glutathione (GSHt) concentration was quantified by the glutathione reductase recycling assay [16]. To estimate the oxidized glutathione (GSSG) level, the protein free sample was treated with 2-vinylpyridine for $60 \mathrm{~min}$ prior to assay at $2 \%$ final concentration [17]. The rate of 5-thionitrobenzoic acid formation was monitored spectrophotometrically at $412 \mathrm{~nm}$. Standards were prepared from GSH, and concentrations were defined as nmol per $\mathrm{g}$ wet weight. The redox-index of glutathione (RIGSH) was calculated as the ratio of concentrations [GSHr][GSH].

Evaluation of oxyradical formation in thyroid gland tissue (1/10 w/v) homogenates was determined using the non-fluorescent derivative, dihydror- 
hodamine, which is converted to the fluorescent dye, rhodamine-123, while reacting with reactive oxygen species [18]. The fluorescence signal was detected by using af-max fluorescence plate-reader [excitation $=485 \mathrm{~nm}$, emission $=538 \mathrm{~nm}]$ immediately, and in $20 \mathrm{~min}$.

Glutathione-S-transferase (GST, EC 2.5.1.18) activity was measured by CDNB as the substrate [19]. Enzymatic activity was determined at $25^{\circ} \mathrm{C}$ by monitoring changes in absorbance at $340 \mathrm{~nm}$ for $2 \mathrm{~min}$. The GST activity was defined as $\mathrm{nmol} \mathrm{min}^{-1} \cdot \mathrm{mg}^{-1}$ soluble protein.

The activity of lactate dehydrogenase (LDH, EC 1.1.1.27) was determined using the UV assay with pyruvate and NADH [20] by determining of the amount of NADH oxidation at $340 \mathrm{~nm}$. Phosphate/ pyruvate solution ( $3 \mathrm{~mL}$ ) (50 mM phosphate, $\mathrm{pH} 7.5$, $0.63 \mathrm{mM}$ pyruvate) was pipetted into cuvettes and $50 \mathrm{~mL}$ NADH solution (11.3 mMb-NADH) was added. Following this, $100 \mathrm{~mL}$ of sample was spiked and mixed. The extinction was checked after very minute interval for a period of $4 \mathrm{~min}$. A molar extinction coefficient of $6.22 \cdot 10^{6} \mathrm{M}^{-1} \cdot \mathrm{cm}^{-1}$ was used.

DNA fragmentation was evaluated by the determination of the levels of protein-free DNA strand breaks in the digestive gland by the alkaline DNA precipitation assay [21] using Hoescht 33342. The reduction of possible interference of traces of SDS in the supernatant was measured in the presence of $0.4 \mathrm{M} \mathrm{NaCl}, 4 \mathrm{mM}$ sodium cholate, and $0.1 \mathrm{M}$ Tris (pH 9). Probe fluorescence signal was detected by using af-max fluorescence plate-reader [excitation = $360 \mathrm{~nm}$, emission = $450 \mathrm{~nm}$ ]. Quantitation was done using known amounts of salmon sperm DNA in the same mixture without addition of sample and determined as ng of protein-free DNA per mg tissue soluble proteins.

Cathepsin D (EC 3.4.23.5) activity was assayed spectrometrically as described previously [22] in incubation mixtures containing buffered haemoglobin solution [4\% (w/v) in $0.25 \mathrm{M}$-sodium acetate buffer, pH5.0].

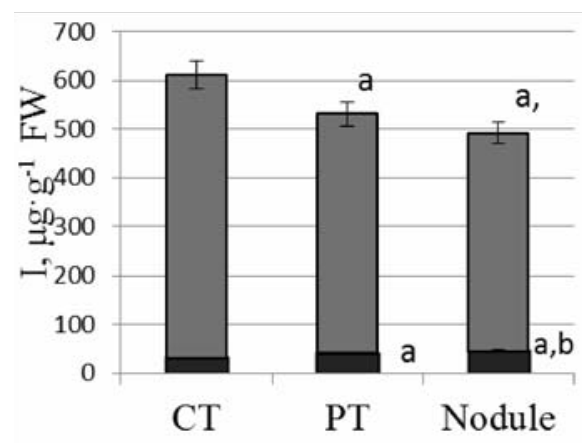

Inorganic $\square$ Organificated
All measurements were carried out using samples from 25 patients. The results were defined as means \pm standard deviation (SD). Data were tested for normality and homogeneity of variance using Kolmogorov-Smirnoff and Levene's tests. Since data were not normally distributed (Lilliefors' test), non-parametric tests (Kruskall-Wallis ANOVA and Mann-Whitney U-test) were performed (significant at $P<0.05$ ). For detection of correlation, the Pearson's correlation test was also performed at a 0.05 level of significance.

Data were subjected to Multiple regression analysis and Principal component analysis (PCA) with NIPALS algorithm to differentiate the group by the set of their indices and select distinguished criterions. Classification trees were built using Classification and Regression Tree (CART) software on the basis of all determined biological characteristics. All statistical calculations were performed by means of Statistica v 8.0 and Excel for Windows 2000.

\section{Results}

The results showed the coherent activation of superoxide dismutase (by $81 \%$ ), catalase (up to two times) and glutathione-transferase (by $212 \%$ ), decrease of GSH level (by $33 \%$ ) and the increase of metallothioneins level (both MT-SH and MT-Me) in affected part of thyroid gland (Fig. 1, 2). Higher level of oxyradicals (by $21 \%$ ) and GSSG (up to $41 \%$ ) has been also detected in these samples. A relation between MT-SH and oxyradical level in thyroid gland was proved. Signs of cytotoxicity, higher free cathepsin D activity (up to $84.6 \%$ and $134.4 \%$ in paranodular tissue and node respectively), and higher level of DNA strand breaks in node (up to $22.6 \%$ ), were observed (Fig. 3). Also, activation of glycolysis in the affected part of thyroid gland was observed. The accumulation of reactive oxygen species $(r=0.72, p<0.01)$ and initiation of oxidative stress in the cell could be the reason for shifting of

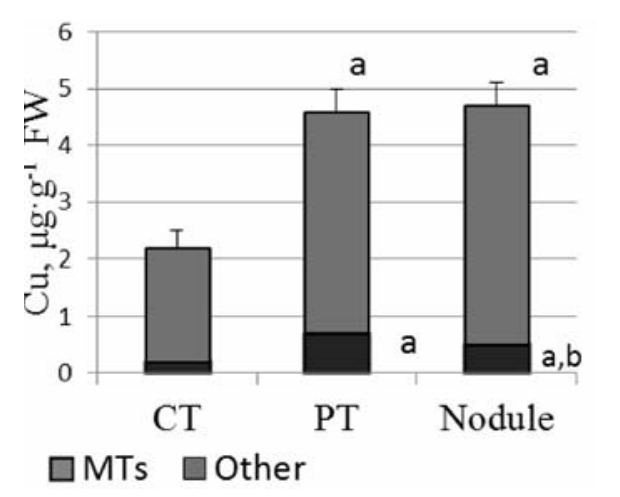

B

A

Fig. 1. Subcellular distribution of iodine (A) and copper (B) in the human thyroid gland under iodine deficiency euthyroid nodular goiter, $\mu \mathrm{g} \times \mathrm{g}^{-1} \mathrm{FW}$, mean $\pm \mathrm{SD}(\mathrm{N}=25)$. In Fig. $1-4$, the significant differences were regarded as $(p<0.05)$; a, differences compare to contralateral part; ${ }^{b}$, differences between paranodular tissue and nodule. 

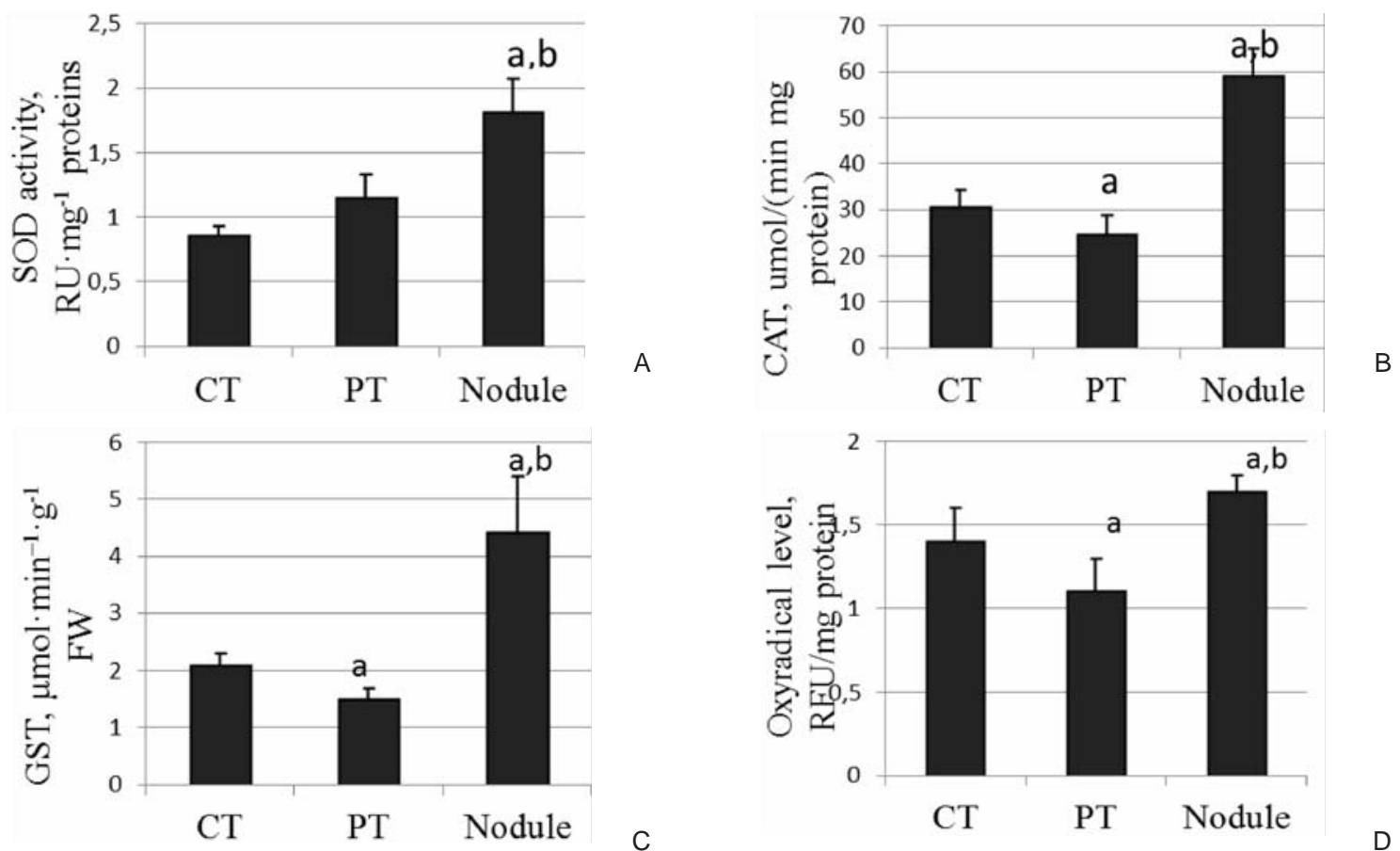

Fig. 2. Oxidative stress parameters in the human thyroid gland under iodine deficiency euthyroid nodular goiter. Data for A: superoxide dismutase, B: catalase, C: glutathione transferase, $\mathrm{D}$ : oxyradical level are present as means $\pm \mathrm{SD}(\mathrm{N}=25)$.

energy balance to anaerobiosis [23]. Range of indices variability in paranodular tissue compared to parenchyma of contralateral part was lesser than in the nodular tissue, but had generally the same trend.

The most important finding was lower level of organificated iodine (by 23 and $15 \%$, respectively) and higher level (by 46 and $32 \%$, respectively) and mass fraction (by $42 \%$ and $82 \%$ respectively) of inorganic iodine in the nodular and paranodular tissue versus contralateral part of thyroid gland (Fig. 4). The disruption of iodine organification in hyperplastic thyrocytes could be caused by elevated copper level (more than twice) in thyroid gland. Copper excess in the affected tissue partly accumulated in MTs. The binding ability of MTs with copper in the nodule was lesser than in the paranodular tissue.

According to PCA test with NIPALS algorithm (Fig. 5, A), two sets were the most distinguished: nodule was characterized by oxidative stress indices, MTs characteristics, and copper distribution, whereas non-affected contralateral part was located jointly with organificated iodine and GSH level. There was no clear characteristic related to the paranollar tissue. Furthermore, it was important to select the main distinguished criterion for pathological process progress at the nodule formation. We used CART analysis (Fig. 5, B) to achieve this. Followed by analysis of all biochemical parameters of every group, the contralateral part of thyroid gland was singled out by its ability to iodine organification. Paranodular tissue and nodule in affected part of

H. Falfushynska et al. thyroid gland were distinguished by level of DNA fragmentation.

\section{Discussion}

It is generally known that nodules develop in pathologically affected thyroid tissue [2]. We established that hyperplastic thyroid epithelium under iodine deficiency nodular colloidal goiter sacrificed its ability for iodine organification and therefore increased of level of inorganic iodine. This pattern designated with higher copper level $(r=0.69$, $p<0.01$ ), manifestation of oxidative damage (increased of SOD, catalase and GST activity $(r=0.73$, $r=0.59$ and $r=0.64$ correspondingly, $\mathrm{p}<0.01$ and MT-SH level $(r=0.97, p<0.001))$ and cytotoxicity (increased DNA fragmentation, $r=0.51, p<0.01$ ) in affected by nodule part of thyroid gland. Therefore, it can be assumed that under deprivation of iodine organification surplus of it has been created in human thyroid gland and determined further formation of iodine toxic intermediates in hyperplastic thyrocytes after its oxidation by thyroperoxidase [24]. This scenario of a stimulating effect on the antioxidant defense system was proved. Similar results, such as increased lipofuscin level, lipid peroxidation, necrosis of epithelial cells, and destabilization of mitochondrial membranes and development of autoimmune processes in the tissue of the thyroid gland were obtained after iodine application in micromolar range into human body [25].

It was proved that apoptosis was among the major determinants of pathological conditions progression [24]. Cathepsin D is a lysosomal 

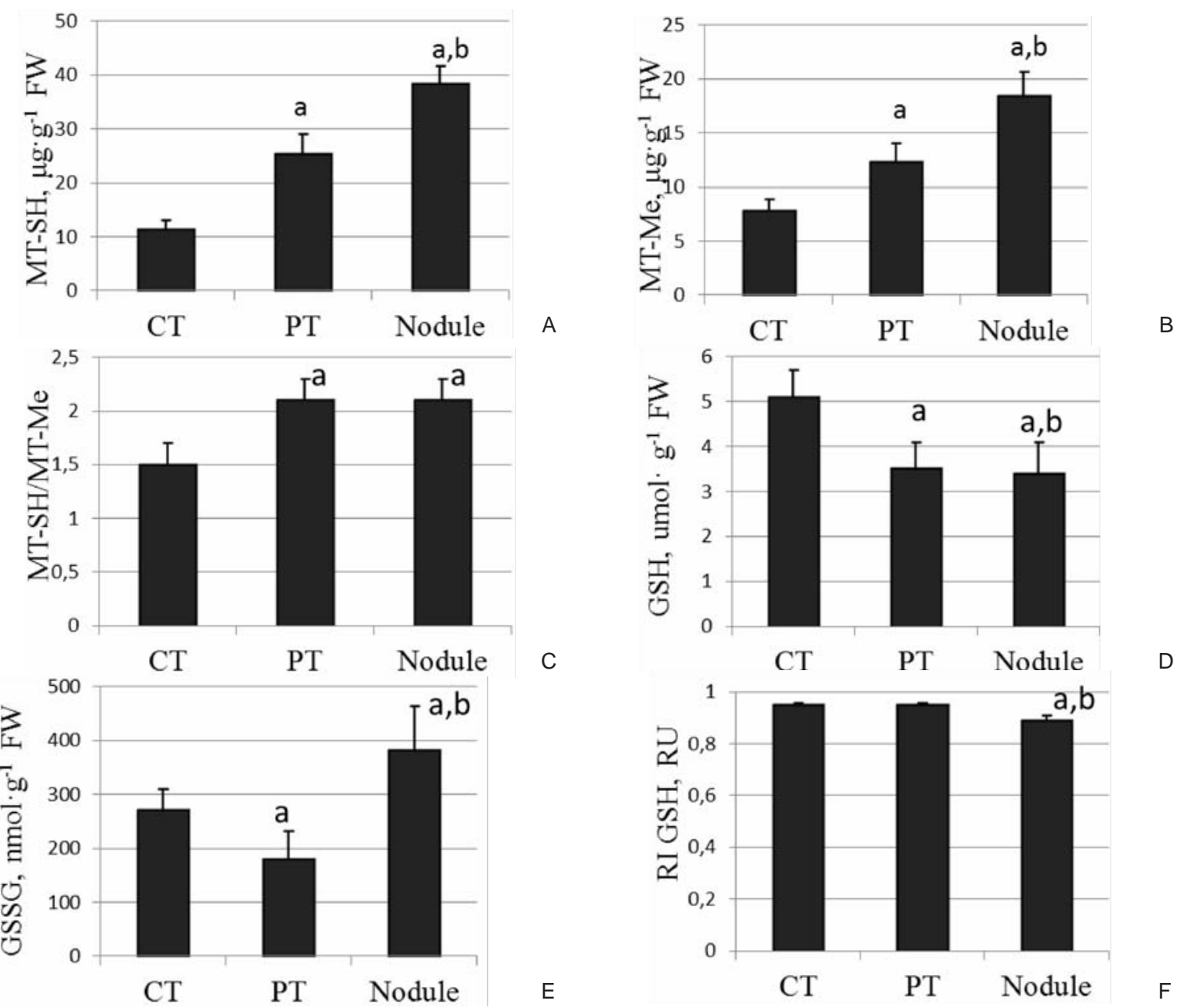

Fig. 3. Characteristics of metallothioneins $(A-C)$ and glutathione $(D-F)$ in the human thyroid gland under iodine deficiency euthyroid nodular goiter. Concentration of MT-SH (A); concentration of MT-Me (B); MT-SH/MT-Me concentration ratio (C); Levels of reduced glutathione (D), oxidized glutathione (E) and redox index of glutathione (RI GSH) (F). The values are expressed as the mean $\pm \mathrm{SD}(\mathrm{N}=25)$.

endopeptidase. It involves in the processing of thyroglobulin, and belongs to mediators of IFN- $\gamma$ and TNF- $\alpha$-induced lysosomal programmed cell death pathway [26]. We were observing its increased level in patients with endemic nodular goiter. It was related to the increase of copper level in the thyroid tissue $(r=0.63, p<0.01)$, and particularly, in potentially toxic, unbound with MTs form $(r=0.67, p<0.01)$. We can speculate that copper accumulated in lysosomes and consistently caused their swelling, activation of calcium-dependent phospholipase A2 [27], and determined destabilization of lysosomal membranes. The in vivo release of the enzymes from the organelles, which happened consequently, has been suggested to play a fundamental role in mediating caspase activation, DNA fragmentation and apoptosis [28].

Recently, it has been shown in vitro that MTs and GSH form a part of the pool of cellular thiols and their function in the cell is cohered [29]. We can conclude the same regulation in human thyroid tissue $(r=-0.79, p<0.001)$ based on our observations. MTs might act as an effective scavenger against reactive oxygen species due to high level of $\mathrm{SH}$-group under weakness of glutathione functional ability, which could indicate a compensatory mechanism. Despite the fact that the MTs level in the cell is lower than GSH, they have exhibited 50x higher antioxidant activity by the molar ratio of thiols[30]. We detected a reverse relation for the MT-SH level and oxyradicals level, which indicated a leading role of MTs in detoxification of oxyradicals: oxyradicals $=-268.4+88.2 \times \mathrm{GSSG}-4.7 \times \mathrm{GSH}+405.5 \times \mathrm{RI}$ $\mathrm{GSH}+6.4 \times \mathrm{GST}-2.1 \times \mathrm{MT}_{-} \mathrm{SH}^{*} ; \mathrm{R}^{2}=0.45, \mathrm{~F}(5,12)=4.7$, $\mathrm{p}<0.03$ ( ${ }^{*}$ - indicated significant contribution into the mathematical model). Similar results were obtained by comparing of goitrous-changed and intact human thyroid gland tissue [4].

\section{Conclusions}

To summarize, the combination of endemic iodine deficiency with a high environmental copper level increases the risk of node formation and progress of pathological changes. At low level of 

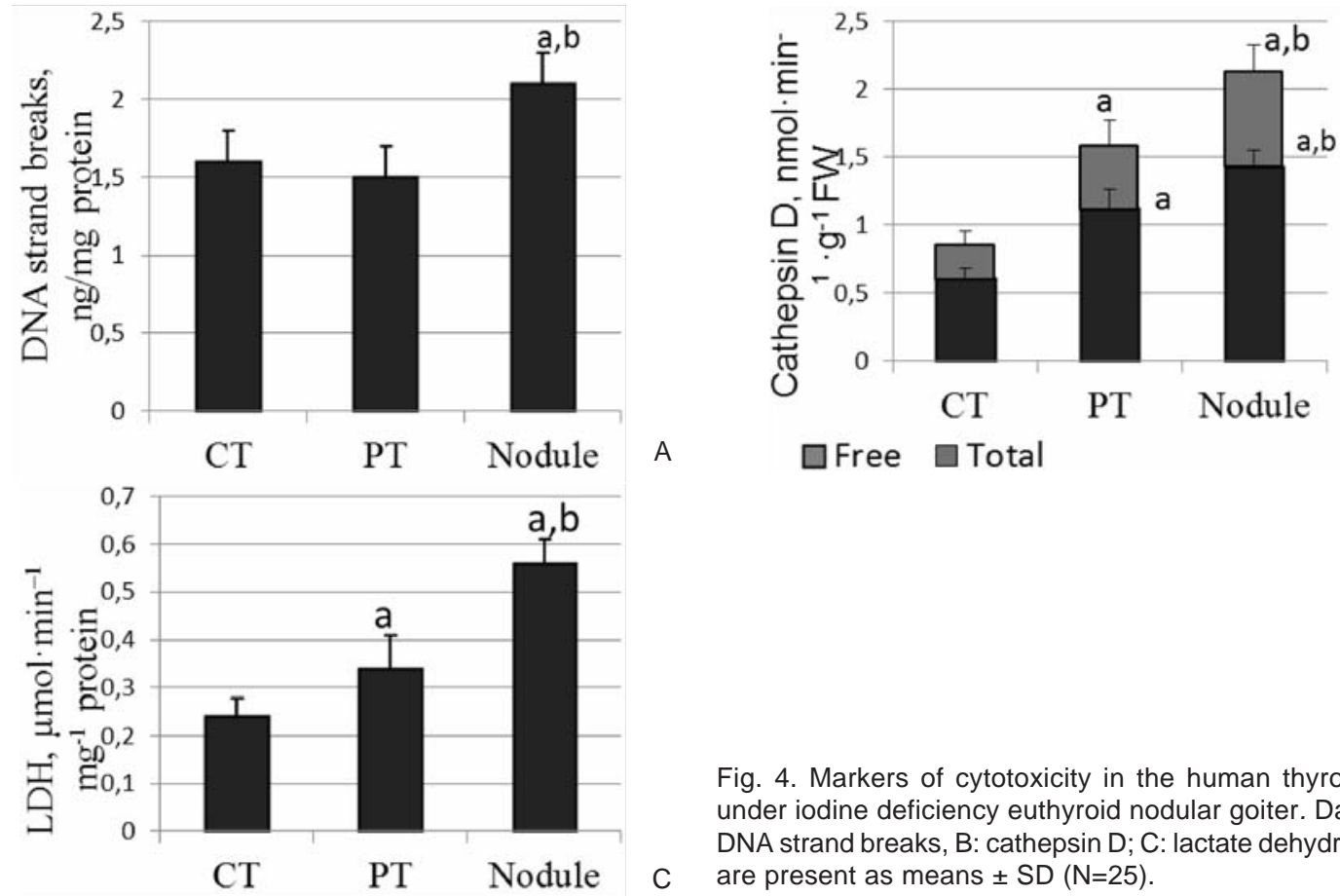

Fig. 4. Markers of cytotoxicity in the human thyroid gland under iodine deficiency euthyroid nodular goiter. Data for A: DNA strand breaks, B: cathepsin D; C: lactate dehydrogenase are present as means $\pm \mathrm{SD}(\mathrm{N}=25)$.

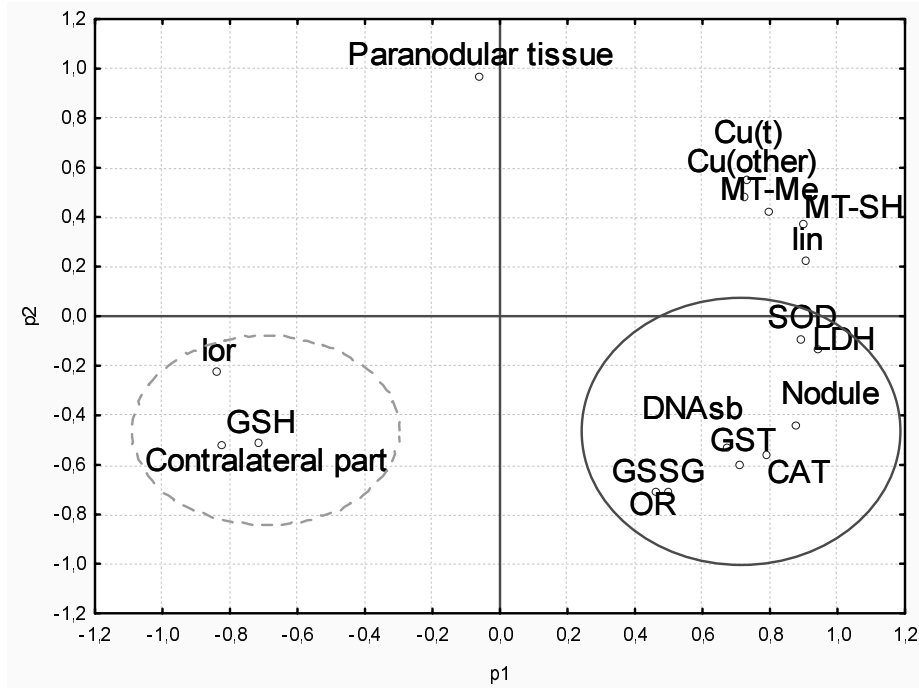

A

Number of splits $=2 ;$ Number of teminal nodes $=3$

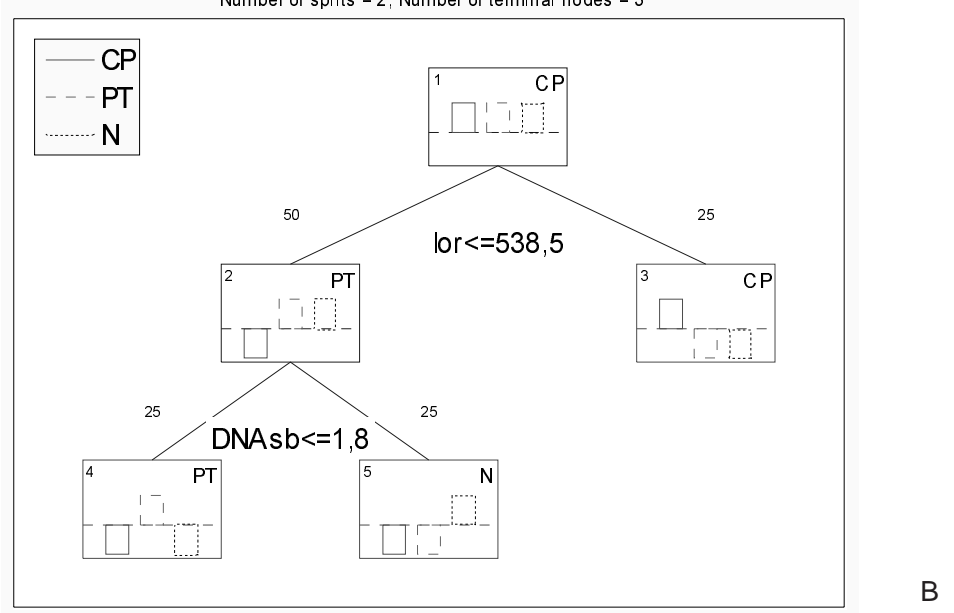

Fig. 5. Principal component analysis with NIPALS algorithm (A) and classification tree models using CART algorithm (B) of total data from human thyroid gland under iodine deficiency euthyroid nodular goiter depending on deepness of pathology processes. Data for B showing node types, split variables, and associated split values of all attributes of tissues. 
iodine organification and high copper level in goitrous tissue of thyroid gland, metallothioneins may provide a partial compensatory effect on prooxidative processes. The effects on the secretion of the cathepsin $\mathrm{D}$ can depend on the accumulation of copper inside thyrocyte lysosomes. Nodule formation in human thyroid gland has been followed by disruption of iodine organification by thyrocytes

\section{References}

1. Giray B, Arnaud J, Sayek I, Favier A, Hincal F. Trace elements status in multinodular goiter. J Trace Elem Med Biol 2010; 24: 106-110.

2. Paschke R. Molecular pathogenesis of nodular goiter.Langenbecks Arch Surg 2011; 396: 1127-1136.

3. Uriu-Adams JY, Keen CL. Copper, oxidative stress, and human health. Mol Aspects Med 2005; 26: 268-298.

4. Фальфушинська ГІ, Гнатишина ЛЛ, ОсадчукДВ, Шідловський ВО, Столяр ОБ. Металодепонуюча фуункція та антиоксидантні властивості щитоподібної залози людей, хворих на йододефіцитний вузловий колоїдний зоб. Укр біохім журн 2011; 83: 92-97.

5. Stolyar OB, Loumbourdis NS, Falfushinska HI, Romanchuk LD. Comparison of metal bioavailability in frogs from urban and rural sites of Western Ukraine. Arch Environ ContamToxicol 2008; 54: 107-113.

6. Jomova K, Valko M. Advances in metal-induced oxidative stress and human disease. Toxicology 2011; 283: 65-87.

7. Maret W. Redox biochemistry of mammalian metallothionein. J Biollnorg Chem 2011; 16: 1079-1086.

8. Ferrario C, Lavagni P, Gariboldi M, Miranda C, Losa M, Cleris L. et al. Metallothionein $1 \mathrm{G}$ acts as an oncosupressor in papillary thyroid carcinoma. Lab Invest 2008; 88: 474-481.

9. Viarengo A, Ponzano E, Dondero F, Fabbri R. A simple spectrophotometric method for metallothionein evaluation in marine organisms: an application to Mediterranean andAntarctic molluscs. Mar Environ Res 1997 44: 69-84.

10. Suzuki KT. Purification of vertebrate metallothioneins. Method Enzymol 1991; 205: 252-263.

11. Falfushynska HI, Gnatyshyna LL, Stoliar OB. Population-related molecular responses on the effect of pesticides in Carassiusauratusgibelio.Comp Biochem Physiol 2012; 155 C: 396-406.

12. Kagi JHR,Schaffer A. Biochemistry of metallothionein. Biochemistry 1988; 27: 8509-8515.

13. Шідловський ВО, Столяр ОБ, Осадчук ДВ, Шідловський ОВ, Фальфушинська ГІ. Деклараційний патент на корисну модель № 45332 (UA), МПК G09B 23/28 (2009.01). Спосіб визначення концентрації йоду в біосубстраті / (Україна). Заявл. 24.04.09; опубл. 10.11.09, Бюл. № 21.

14. Beauchamp C, Fridovich I. Superoxide dismutase: improved assay and an assay applicable to acrylamide gels. Anal Biochem 1971; 44: 276-287.

15. Aebi H. Catalase (in) Bergmeyer HU. (ed.) Methods of Enzymatic Analysis. Academic Press, London; 1974: 671-684.

16. Anderson ME. Determination of glutathione and (general characteristic of affected by nodule tissue) and increased level of DNA fragmentation (specific character of the nodule).

\section{Acknowledgements}

This work has been granted by the Ministry of Education and Science of Ukraine (Project \# 125B), State Fund of Fundamental Research (GF/056/017) and West Ukrainian Biomedical Research Center.

glutathione disulfide in biological samples. Meth Enzymol 1985;113: 548-555.

17. Griffith OW. Determination of glutathione and glutathione disulfide using glutathione reductase and 2vinylpyridine. Anal Biochem 1980; 106: 207-212.

18. Viarengo A, Burlando B, Cavaletto M, Marchi B, Ponzano E, Blasco J. Role of metallothionein against oxidative stress in the mussel Mytilusgalloprovincialis. Am J Physiol 1999; 277: 1612-1619.

19. Habig WH, Pabst MJ, Jakoby WB. Glutathione S-transferases. The first enzymatic step in mercapturic acid formation. J Biol Chem 1974; 249: 7130-7139.

20. Bergmeyer HU, Bernt E. Lactate-dehydrogenase, UV-assay with pyruvate and $\mathrm{NADH}$ (in) Bergmeyer HU. (ed.) Methods of enzymatic analysis. Vol 2. Academic Press, New York; 1974: 579.

21. Olive PL. DNA precipitation assay: a rapid and simple method for detecting DNA damage in mammalian cells. Environ Mol Mutagen 1988; 11: 487-495.

22. Dingle JT, Barrett AJ, Weston PD. Cathepsin D. Characteristics of immunoinhibition and the confirmation of a role in cartilage break down. Biochem J 1971; 123: 1-13.

23. Morita M, Noguchi S, Kawamoto H, Tajiri J, Tamaru M, Murakami N. Thyroglobulin and lactic dehydrogenase isozymes in cystic fluid of thyroid nodules. Endocr J 1994; 41: 227-233.

24. Vitale M, Di Matola T, D’Ascoli F, Salzano S, Bogazzi F, Fenzi G. et al. lodide excess induces apoptosis in thyroid cells through a p53-independent mechanism involving oxidative stress. Endocrinology 2000; 141:598-605.

25. Foley TP Jr. The relationship between autoimmune thyroid disease and iodine intake: a review. Endokrynol Pol 1992; 43, Suppl 1: 53-69.

26. Tsukuba T, Okamoto K, Yasuda Y, Morikawa W, Nakanishi H, Yamamoto K. New functional aspects of cathepsin D and cathepsin E. Mol Cells 2000; 10: 601-611.

27. Marchi B, Burlando B, Moore MN, Viarengo A. Mercury- and copper-induced lysosomal membrane destabilisation depends on $\left[\mathrm{Ca}^{2+}\right]$ i dependent phospholipase A2 activation. Aquat Toxicol 2004; 66: 197-204.

28. Persson HL. Iron-dependent lysosomal destabilization initiates silica-induced apoptosis in murine macrophages. Toxicol Lett 2005; 159: 124-133.

29. Hidalgo J, Garvey JS, Armario AJ. On the metallothionein, glutathione and cysteine relationship in rat liver. Pharmacol Exp Ther 1990; 255: 554-564.

30. Thornalley PJ, Vasak M. Possible role for metallothionein in protection against radiation-induced oxidative stress. Kinetics and mechanism of its reaction with superoxide and hydroxyl radicals. Biochim Biophys Acta 1985; 827: 36-44. 